\title{
Performance and stability analysis of some sugarcane genotypes across different environments
}

\author{
Ali, M.A. ${ }^{*}$, M.S. Hassan ${ }^{1}$, B.D. Mohamed ${ }^{2}$ and M.H. Ali ${ }^{2}$ \\ ${ }^{1}$ Department of Agronomy, Faculty of Agriculture, South Valley University, Qena, Egypt \\ ${ }^{2}$ Sugar Crops Research Institute, Agriculture Research Center, Giza, Egypt
}

\begin{abstract}
Eleven genotypes of sugarcane (ten genotypes and one commercial variety G.T.54-9 as a control) were evaluated at twelve environments; three locations (Agric. Res. Stations of Kom-Ombo, Aswan governorate, El-Mataana, Luxor governorate and Shandaweel, Sohag governorate and two harvesting dates; 11 and 12 month-old in 2015/2016 (plant-cane) and 2016/2017 (first-ratoon).The differences among genotypes, locations and between harvesting dates were significant for all studied traits; stalk length, stalk weight, cane yield, brix, sucrose and sugar yield. The interaction of locations $\times$ genotypes was highly significant in plant-cane and first-ratoon for all studied traits. Locations $\times$ harvesting dates interaction was significantly for stalk length in plant-cane crop and for stalk weight, sucrose and sugar yield in first-ratoon crop. Mean squares due to interaction between genotypes, harvesting dates and locations were significantly for all studied traits, except cane and sugar yields in plant-crop and stalk length in first-ratoon. Mean cane yield ranged from 54.23 and 52.61 to 57.61 and $56.71 \mathrm{t} /$ fed at harvesting dates and from 46.66 and 50.12 to 60.71 and $58.69 \mathrm{t} / \mathrm{fed}$ under locations in plant-cane and first-ratoon, respectively. Late harvesting date increased cane yield and its components. The stability analysis of variance for cane yield showed that the intermediate yielding genotypes (G.2003-47, G.2004-27 and G.2011-82) were more stable than the rather responsive high yielding ones. However, the genotype G. 2004-27 was stable for cane yield and its components. In addition, it was considered to be superior for cane yield under different environments. However, the highest yielding genotype (G.99-103) was unstable.
\end{abstract}

Keywords: Sugarcane; Performance; Stability, Interaction

\section{Introduction}

Sugarcane is one of the major cash crops grown extensively all over the world from tropical to subtropical regions. Egypt is the first country in productivity of sugarcane by 8647219 tons of cane resulted from 248220 faddan(faddan $=0.42$ ha.) produced 930250 tons of sugar, (Annual Report of Sugar crops Council, 2019). The great challenge faces the sugar industry from sugarcane is the lacking of

*Corresponding author: Dionesio M. Bañoc

Email: dionesio.banoc@vsu.edu.ph

Received: July 29, 2020;

Accepted: September 6, 2020;

Published: September 13, 2020. the commercial varieties. Furthermore, the Egyptian sugarcane-breeding program is working hard to develop new sugarcane varieties having high and stable yield of cane and sugar, in addition to, resistance to diseases, pests and adverse conditions. High and stable cane and sugar yields of sugarcane genotypes across varying environments of production regions are the basic and desirable traits for selection in all sugarcane-breeding programs. Therefore, elite sugarcane genotypes normally evaluated in multi-environments trails, which take into account the multiple harvest nature 
and maturity pattern of the sugarcane crop. Harvesting of sugarcane extends for five months at least and it involves more than one crop class, i.e., plant-cane and ratoon crops which are different in growing seasons and years. Eberhart and Russell (1966) model has been widely used in studies of adaptability and stability of genotypes, the most desired and stable genotypes can be considered when their regression coefficient equal one $(b i=1)$ with mean square deviations from regression (S2di) closed zero. The differences in relative performance of sugarcane genotypes due to the differences in GE interaction in different environments were found and significant genotype - environment interactions were reported by (Queme et al., 2005, Rea et al., 2014;Guddadamathet al., 2014; Rea et al., 2015; Sphamandla et al., 2017; Premaet al., 2017).The objective of this study was estimation the performance and stability of tested elite genotypes for cane, sugar yields and related components across the entire range of environments in three production areas in Egypt.

\section{Materials and Methods}

The present investigation was carried out under Upper Egypt conditions during 2015/2016 and 2016/2017 growing seasons. Ten new genotypes of sugarcane (Saccharum officinarum L.); G. 84-7, G. 99-103, G. 200344, G. 2003-47, G. 2003-49, G. 2004-27, G. 2007-61, G. 2010-7, G. 2010-26 and G. 201182 in addition to the commercial variety G.T.54-9 as a control were used in this study.

The eleven genotypes were evaluated at twelve environments (six environments for each year). These environments included three locations, i.e., Kom-Ombo Agric. Res. Station, Aswan, governorate, El-Mataana Agric. Res. Station, Luxor governorate and Shandaweel Agric. Res. Station, Sohag governorate and two harvesting dates; 11 and 12 month-old. The genotypes were planted in the first week of March in 2015/16 season. The harvesting dates of the plant-cane and its first-ratoon crops were 11 and 12 month-old from planting in plant crop, or from harvesting plant-cane for the firstratoon crop.

The experimental design was a randomized complete block in split-plot arrangement with three replications at each location. The two harvesting dates were applied to the main plots, while the sugarcane genotypes were randomly distributed on the subplots. The experimental unit area was $56 \mathrm{~m} 2$ including eight rows of $7 \mathrm{~m}$ long and one meter apart.

The traits were studied at each harvesting date, i.e., stalk length, stalk weight, cane yield, brix, sucrose, and sugar yield.

\section{Statistical analysis}

The combined analysis of variance was performed according to Gomez and Gomez (1984). The stability analysis for all studied traits was carried out according to Eberhart and Russell (1966). The means of genotypes were compared using the Revised Least Significant Difference (RLSD) method at $5 \%$ and $1 \%$ of probability.

\section{Results and Discussion}

The differences among locations and between harvesting dates were highly significant for all studied traits; stalk height, stalk weight, cane yield, brix, sucrose and sugar yield in the two seasons (2015/2016; plant-cane and 2016/2017; first-ratoon). This indicates that the wide differences in climatic and edaphically factors prevailing at the three locations. The studied genotypes as well highly significant differed for all studied traits in each of plant-cane and first-ratoon, for all studied traits. Locations $\times$ harvesting dates interaction was highly significant for stalk length stalk weight, sucrose and sugar 
yield in first-ratoon crop. In addition, mean squares due to interaction between genotypes, harvesting dates and locations were significant and highly significant for four of them in plantcrop and for five of them in first-ratoon (Tables 1).Accordingly, there were a differential response between genotypes to harvesting dates and locations.

\section{A- The performance of genotypes:}

\section{a1- Stalk length}

Mean stalk length ranged from 288.2 to $290.4 \mathrm{~cm}$ and from 265.1 to $309.2 \mathrm{~cm}$ for harvesting dates and locations in plant-cane, respectively (Table 2 ). However, it ranged from 283.6 to $285.4 \mathrm{~cm}$ and from 263.5 to $296.2 \mathrm{~cm}$ for harvesting dates and locations in firstratoon, respectively (Table 2). The average stalk length of the eleven genotypes ranged from 244.8 and 214.8 (G. 2010-26) to 311.9 (G.84-47) and 303.3 (G. 2010-7) with an overall average of 289.3 and $284.4 \mathrm{~cm}$ in plantcane and first-ratoon, respectively (Table 3 ). The tallest genotype was G. 99-103 (335.0 and $321.0 \mathrm{~cm}$ in plant-cane and first-ratoon, respectively) at Kom-Ombo in the second harvesting date (Table 3). From data (Tables 3), five genotypes (G.84-47, G.99-103, G.200344, G.2004-27 and G.2010-7) were taller than the control variety (G.T.54-9). This indicates that these genotypes had accumulated favorable alleles for tallness and could be used in future breeding programs. Ahmed (2003), Osman et al. (2011), Hagos et al. (2014 b) and Ahmed et al. (2016 a) reported that delay harvesting date up to 14 months gave the highest values of stalk height in plant-cane and 1stratoon-crops.

\section{a2-Stalk weight}

Results in Table 2 illustrated that most genotypes under late harvesting date gave heavier stalk weight than early harvesting one in both plant-cane and first-ratoon crops. Late harvesting date gave $1.46,1.45$ and $1.17 \mathrm{~kg}$ compared to $1.38,1.38$ and $1.05 \mathrm{~kg}$ for early harvesting date at L1, L2 and L3 in plant-cane, respectively. While, it gave $1.31,1.03$ and 1.18 $\mathrm{kg}$ compared to $1.14,1.03$ and $1.10 \mathrm{~kg}$ for early harvesting at L1, L2 and L3 in first-ratoon, respectively. The average stalk weight of the eleven genotypes ranged from 1.11 (G.201182) and 0.98 (G. 2010-26) to 1.70 and 1.43 (G.99-103) with an overall average of 1.31 and $1.13 \mathrm{~kg}$ in plant-cane and first-ratoon, respectively. It noticed that the genotypes G.99-103 and G.2010-7 in plant-cane as well as two genotypes; G.99-103 and G.2004-27 in first-ratoon were heavier in stalk weight than the control variety; G.T.54-9 (Table 4).Ahmed (2003) and Osman et al. (2011) concluded that the 14-month-old was the most suitable age for harvesting whether for plant-cane or ratooncrops on stalk weight.

\section{a3-Cane yield}

The average cane yield of the various genotypes ranged from 54.23 to $57.61 \mathrm{t} /$ fed and from 46.66 to $60.71 \mathrm{t} /$ fed for harvesting dates and locations in plant-cane, respectively (Table 2). In addition, it ranged from 52.61 to 56.71 t/fed and from 50.12 to $58.69 \mathrm{t} /$ fed for harvesting dates and locations in first-ratoon, respectively (Table 2). The early harvesting date gave 59.55, 58.92 and 44.21 compared with $61.78,61.94$ and $49.11 \mathrm{t} /$ fed produced from late harvesting date at L1, L2 and L3 in plant-cane, respectively. In addition, it gave 54.61, 54.87and 48.35 compared to 62.77 , 55.48 and $51.88 \mathrm{t} /$ fed for late harvesting date at L1, L2 and L3 in first-ratoon, respectively. Genotypes showed differential responses for either harvesting dates or locations for cane yield (Table 5). The average cane yield of the different genotypes ranged from 48.02 and 39.66 (G. 2010-26) to 64.09 and 62.31 (G.99103) with an overall average of 55.92 and 54.66 t/fed in plant-cane and first-ratoon, respectively (Table 5). In the late harvesting 
Table 1. Mean squares of the combined analysis of variance for the studied traits of 11 genotypes over 6 environments in the two seasons (2015/2016; plant-cane and 2016/2017; first-ratoon).

\begin{tabular}{|c|c|c|c|c|c|c|c|c|c|c|c|c|c|}
\hline \multirow[b]{2}{*}{ S. O. V } & \multirow[b]{2}{*}{$\mathrm{df}$} & \multicolumn{6}{|c|}{ 2015/2016 (plant-cane) } & \multicolumn{6}{|c|}{ 2016/2017 (first-ratoon) } \\
\hline & & $\begin{array}{l}\text { Stalk length } \\
\quad(\mathrm{cm})\end{array}$ & $\begin{array}{c}\text { Stalk } \\
\text { weight } \\
(\mathrm{kg})\end{array}$ & $\begin{array}{l}\text { Cane yield } \\
\text { (t/fed) }\end{array}$ & $\operatorname{Brix}(\%)$ & $\begin{array}{c}\text { Sucrose } \\
(\%)\end{array}$ & $\begin{array}{c}\text { Sugar } \\
\text { yield } \\
\text { (t/fed) }\end{array}$ & $\begin{array}{l}\text { Stalk length } \\
\quad(\mathrm{cm})\end{array}$ & $\begin{array}{c}\text { Stalk } \\
\text { weight } \\
\text { (kg) }\end{array}$ & $\begin{array}{l}\text { Cane yield } \\
\text { (t/fed) }\end{array}$ & $\begin{array}{l}\text { Brix } \\
(\%)\end{array}$ & $\begin{array}{c}\text { Sucrose } \\
(\%)\end{array}$ & $\begin{array}{c}\text { Sugar } \\
\text { yield } \\
\text { (t/fed) }\end{array}$ \\
\hline Locations (L) & 2 & $33382.36^{* *}$ & $2.068^{* * *}$ & $4245.31^{* *}$ & $67.68^{* *}$ & $70.27^{* *}$ & $51.06^{* * *}$ & $21889.02^{* *}$ & $0.636^{*}$ & $1224.97^{*}$ & $26.87^{* *}$ & $86.55^{* *}$ & $46.63^{* *}$ \\
\hline Error (a) & 6 & 59.85 & 0.034 & 121.97 & 1.79 & 1.39 & 1.52 & 11.99 & 0.075 & 222.48 & 0.63 & 0.59 & 3.71 \\
\hline Harvesting $(\mathrm{H})$ & 1 & $1693.14^{* * *}$ & $0.397^{* *}$ & $566.29^{*}$ & $96.01^{* * *}$ & $45.85^{* *}$ & $17.46^{* *}$ & $158.23^{* *}$ & $0.350^{* *}$ & $833.45^{* *}$ & $83.41^{* *}$ & $124.63^{* *}$ & $47.50^{* *}$ \\
\hline $\mathrm{L} \times \mathrm{H}$ & 2 & $878.61^{\text {** }}$ & 0.011 & 31.06 & 0.99 & 1.93 & 1.41 & 2.02 & $0.111^{*}$ & 238.66 & 1.96 & $9.66^{* *}$ & $3.10^{*}$ \\
\hline Error (b) & 6 & 34.47 & 0.029 & 73.37 & 0.50 & 0.87 & 0.74 & 2.83 & 0.013 & 52.16 & 0.46 & 0.49 & 0.51 \\
\hline Genotypes (G) & 10 & $5977.09^{* * *}$ & $0.479^{* *}$ & $302.01^{* *}$ & $14.32^{* * *}$ & $20.44^{* *}$ & $4.29^{* *}$ & $11446.78^{* *}$ & $0.246^{* * *}$ & $610.41^{* *}$ & $10.69^{* *}$ & $18.49^{* *}$ & $8.61^{* * *}$ \\
\hline $\mathrm{L} \times \mathrm{G}$ & 20 & $1289.41^{* *}$ & $0.081^{* *}$ & $480.99^{* *}$ & $1.02^{* *}$ & $1.77^{* *}$ & $4.56^{* *}$ & $2211.89^{* * *}$ & $0.153^{* *}$ & $387.50^{* *}$ & $3.28^{* *}$ & $5.46^{* *}$ & $4.98^{* *}$ \\
\hline $\mathrm{H} \times \mathrm{G}$ & 10 & $118.64^{* *}$ & 0.027 & 23.98 & 0.53 & 0.94 & 0.53 & $2.58^{*}$ & 0.009 & 28.47 & $2.32^{* *}$ & $2.70^{* *}$ & $0.76^{\text {** }}$ \\
\hline $\mathrm{L} \times \mathrm{H} \times \mathrm{G}$ & 20 & $85.34^{* *}$ & $0.036^{*}$ & 26.62 & $1.20^{*}$ & $1.83^{* *}$ & 0.61 & 1.69 & $0.013^{*}$ & $36.54^{*}$ & $0.54^{* *}$ & $0.77^{*}$ & $1.55^{\text {** }}$ \\
\hline Error (c) & 120 & 28.86 & 0.020 & 64.45 & 0.45 & 0.83 & 0.62 & 1.36 & 0.008 & 22.01 & 0.23 & 0.45 & 0.30 \\
\hline
\end{tabular}

*, ** Significant at 0.05 and 0.01 probability levels, respectively.

Table 2. Means of the studied traits over genotypes for locations and harvesting dates in the two seasons (2015/2016; plant-cane and 2016/2017; first-ratoon).

\begin{tabular}{|c|c|c|c|c|c|c|c|c|c|c|c|c|c|}
\hline \multirow{2}{*}{\multicolumn{2}{|c|}{ Item }} & \multicolumn{6}{|c|}{ 2015/2016 (plant-cane) } & \multicolumn{6}{|c|}{ 2016/2017 (first-ratoon) } \\
\hline & & \multirow{2}{*}{$\begin{array}{c}\begin{array}{c}\text { Stalk } \\
\text { length }(\mathrm{cm})\end{array} \\
307.8 \\
\end{array}$} & \multirow{2}{*}{$\begin{array}{c}\begin{array}{c}\text { Stalk } \\
\text { weight } \\
(\mathrm{kg})\end{array} \\
1.42 \\
\end{array}$} & \multirow{2}{*}{$\begin{array}{c}\text { Cane yield } \\
\text { (t/fed) }\end{array}$} & \multirow{2}{*}{$\begin{array}{c}\text { Brix (\%) } \\
20.14 \\
\end{array}$} & \multirow{2}{*}{$\begin{array}{c}\text { Sucrose } \\
(\%) \\
17.40 \\
\end{array}$} & \multirow{2}{*}{$\begin{array}{c}\begin{array}{c}\text { Sugar } \\
\text { yield } \\
\text { (t/fed) }\end{array} \\
6.98 \\
\end{array}$} & \multirow{2}{*}{$\begin{array}{c}\begin{array}{c}\text { Stalk } \\
\text { length }(\mathrm{cm})\end{array} \\
293.8 \\
\end{array}$} & \multirow{2}{*}{$\begin{array}{c}\begin{array}{c}\text { Stalk } \\
\text { weight } \\
(\mathrm{kg})\end{array} \\
1.24 \\
\end{array}$} & \multirow{2}{*}{$\begin{array}{c}\begin{array}{c}\text { Cane yield } \\
(\mathrm{t} / \mathrm{fed})\end{array} \\
58.69 \\
\end{array}$} & \multirow{2}{*}{$\begin{array}{r}\text { Brix } \\
(\%)\end{array}$} & \multirow{2}{*}{$\begin{array}{c}\text { Sucrose } \\
(\%) \\
18.66 \\
\end{array}$} & \multirow{2}{*}{$\begin{array}{c}\begin{array}{c}\text { Sugar } \\
\text { yield } \\
\text { (t/fed) }\end{array} \\
6.88 \\
\end{array}$} \\
\hline Locations & $\mathrm{L}_{1}$ & & & & & & & & & & & & \\
\hline & $\mathrm{L}_{2}$ & 295.0 & 1.42 & 60.43 & 18.61 & 15.46 & 5.72 & 296.2 & 1.03 & 55.18 & 20.26 & 16.37 & 5.59 \\
\hline & $\mathrm{L}_{3}$ & 265.2 & 1.11 & 46.66 & 20.53 & 17.04 & 5.28 & 263.5 & 1.14 & 50.12 & 21.30 & 17.61 & 5.30 \\
\hline \multirow[t]{2}{*}{ Harvesting date } & $\mathrm{H}_{1}$ & 288.2 & 1.27 & 54.23 & 19.06 & 16.15 & 5.61 & 283.6 & 1.09 & 52.61 & 20.35 & 16.75 & 5.43 \\
\hline & $\mathrm{H}_{2}$ & 290.4 & 1.36 & 57.61 & 20.45 & 17.11 & 6.29 & 285.4 & 1.17 & 56.71 & 21.65 & 18.34 & 6.41 \\
\hline
\end{tabular}

$\mathrm{L}_{1}=$ Kom-Ompo $\mathrm{L}_{2}=$ El-Mattana $\mathrm{L}_{3}=$ Shandaweel $\mathrm{H}_{1}=$ Early harvesting date $\mathrm{H}_{2}=$ Late harvesting dat 
date, the highest cane yield were observed for the genotype G.99-103 (85.98 t/fed.) at ElMattana and the genotype G.2007-61(79.75 t/fed.) at Kom-Ombo in plant-cane and firstratoon, respectively (Table 5). The results showed that half genotypes were higher in cane yield than the control variety (G.T.54-9), indicating that these genotypes could be used in future breeding programs. These results are in harmony with those obtained by Arumugam et al. (2002), Ahmed (2003), Ramburan et al. (2009), Osman et al. (2011), Abd El-Razek and Besheit (2012), Bashir et al. (2012), Hagos et al. (2014 b), Ahmed et al. (2016 a) and Mehareb and Sakina (2017) who concluded that cane yield increased with increase of crop age up to 13-14 month-old. Bashir et al. (2013) and Abdul Khaliq et al. (2018) found that the highest cane yield was in February in both different cropping seasons. Hamam et al. (2015) found that delaying harvesting times of sugarcane from 11 to 14 month-old caused increasing cane yield of sugarcane from 51.42 to $61.23 \mathrm{t} /$ fed and from 58.37 to $63.35 \mathrm{t} / \mathrm{fed}$ in the first and second seasons, respectively.

\section{a4- Brix}

The early harvesting date gave brix percentage of $19.46,18.02$ and 19.70 compared with $20.81,19.20$ and $21.35 \%$ for late harvesting one at L1, L2 and L3 in plant-cane, respectively. In addition, it gave 20.84, 19.42 and 20.78 compared to $22.00,21.11$ and $21.83 \%$ for late harvesting date at L1, L2 and L3 in first-ratoon, respectively. Genotypes showed differential responses for either harvesting dates or locations for brix (Table 6). The average brix percentage of the different genotypes ranged from 17.84 and 19.33 (G.2010-7) to 20.68 and 21.93 (G.2003-47) with an overall average of 19.76 and $20.99 \%$ in plant-cane and first-ratoon, respectively (Table 6). The highest percentage of brix was obtained from the genotype G.2010-26 (22.44\%) at Shandaweel and the genotype G.84-47 $(23.50 \%)$ at Kom-Ombo in plant-cane and firstratoon, respectively (Table 6). Most of genotypes were higher in percentage of brix than the control variety (G.T.54-9). Ahmed (2003), Hagos et al. (2014a), Hagos et al. (2014 b), Ahmed et al. (2016 a) found that brix was significantly influenced by delaying the harvesting ages from 12 to 14 month-old either in plant-cane or first-ratoon. Mebrahtom et al. (2017) suggested that brix accumulation of the studied genotypes depends on crop-age, which governed by location.

\section{a5-Sucrose}

The early harvesting date gave sucrose percentage of 16.84, 15.17 and 16.44compared with $17.95,15.74$ and $17.64 \%$ for late harvesting one at L1, L2 and L3 in plant-cane, respectively. In addition, it gave 18.00, 15.14 and 17.10 compared to $19.31,17.59$ and $18.11 \%$ for late harvesting date at L1, L2 and L3 in first-ratoon, respectively. Genotypes showed differential responses for either harvesting dates or locations for sucrose (Table 7). The average sucrose percentage of the different genotypes ranged from 14.17 and 15.90 (G.2010-7) to 17.93(G.2003-47) and 19.17 (G.2003-49) with an overall average of 16.63 and $17.54 \%$ in plant-cane and firstratoon, respectively (Table 7). The highest percentage of sucrose was obtained from the genotype G.2003-47 (19.47\%) and the genotype G.84-47 (21.21\%) at Kom-Ombo for late harvesting date in plant-cane and firstratoon, respectively (Table 7). Most of the studied genotypes were higher in percentage of sucrose than the control variety (G.T.54-9) in plant-cane, while, three genotypes were higher in percentage of sucrose than the control variety (G.T.54-9) in first-ratoon. Ahmed (2003) and Ahmed et al. (2016 a) indicated that 
sucrose increased with the increase of crop age from 10 to 12 month-old. Viator et al. (2010) indicated that early harvesting date of both plant-cane and first-ratoon reduced sucrose yield for all cultivars compared to the midseason harvesting date. Rakkiyappanet al. (2009), Yohannes and Netsanet (2014) and Priyankaet al. (2016) found that juice sucrose increased at the 13 month-old followed by at 14 month-old.

\section{a6- Sugar yield}

The average sugar yield of the various genotypes ranged from 5.61 to $6.29 \mathrm{t} /$ fed and from 5.28 to $6.98 \mathrm{t} /$ fed for harvesting dates and locations in plant-cane, respectively (Table 2). In addition, it ranged from 5.43 to $6.41 \mathrm{t} / \mathrm{fed}$ and from 5.30 to $6.88 \mathrm{t} / \mathrm{fed}$ for harvesting dates and locations in first-ratoon, respectively (Table 2). The early harvesting date gave 6.74, 5.54 and 4.82 compared with 7.22, 5.91 and $5.75 \mathrm{t} /$ fed produced from late harvesting date at L1, L2 and L3 in plant-cane, respectively. In addition, it gave 6.20, 5.05 and 5.05 compared to $7.56,6.12$ and $5.55 \mathrm{t} /$ fed for late harvesting date at L1, L2 and L3 in first-ratoon, respectively. Genotypes showed differential responses for either harvesting dates or locations for sugar yield (Table 8). The average sugar yield of the different genotypes ranged from 5.27(G. 2010-7) and 4.29 (G. 2010-26) to 6.87(G. 2003-47) and 6.70 (G.T. 54-9) with an overall average of 6.00 and $5.92 \mathrm{t} /$ fed in plantcane and first-ratoon, respectively (Table 8). The highest sugar yield were observed for the genotype G. 2003-47 (8.86 t/fed.) and the genotype G.84-47 (8.98 t/fed.) in late harvesting date at Kom-Ombo in plant-cane and first-ratoon, respectively (Table 8).Most of the studied genotypes were higher in sugar yield than the control variety (G.T.54-9) in plant-cane, while, all genotypes were lower in sugar yield than the control variety (G.T.54-9) in first-ratoon. Similar results were obtained by Arumugam et al. (2002), Ahmed (2003), Osman et al. (2011), Abd El-Razek and Bekheit (2012), Hagos et al. (2014a and b), and Ahmed et al. (2016 a) who found that the harvesting date up to 14 months gave the highest values of sugar yield in plant-cane and 1stratoon crops over the other harvesting dates. Gilbert et al. (2006) and Viator et al. (2010) found that early harvesting date of both plant-cane and firstratoon reduced sugar yields for all cultivars compared to the mid-season harvesting date. On the other hand, sugar yield decreased from 7.76 to $6.47 \mathrm{t} / \mathrm{fed}$ and from 8.30 to $7.63 \mathrm{t} /$ feddan with delaying harvesting times from 13 to 14 months in the first and second seasons, respectively (Hamam et al., 2015). Harvesting age at 13 month-old not significantly, increased sugar yield compared with harvesting at 12 months in plant-cane and first-ratoon (Mehareb and Sakina, 2017).

From previous results declared significant effects of locations and harvesting dates and their different order interactions on the different genotypes for most of the studied traits. This means that the studied genotypes responded differently for harvesting dates and locations, which caused difficulty in demonstrating the significant superiority of any genotype for all locations and harvesting dates. Therefore, it may be informative to study the stability parameters of each genotype.

\section{B- Stability analysis}

The joint regression analysis of variance for stalk length, stalk weight, cane yield, brix, sucrose and sugar yield are listed in Table 9. The differences among genotypes were highly 
Ali et al., SVU-International Journal of Agricultural Sciences, 2 (2): 192-213, 2020

Table 3. Average performance of 11 genotypes in two seasons, at three locations and two harvesting dates for stalk length.

\begin{tabular}{|c|c|c|c|c|c|c|c|c|c|c|c|c|c|c|}
\hline \multirow[t]{3}{*}{ Genotypes } & \multicolumn{7}{|c|}{ 2015/2016 (plant-cane) } & \multicolumn{7}{|c|}{ 2016/2017 (first-ratoon) } \\
\hline & \multicolumn{2}{|c|}{$\mathrm{L}_{1}$} & \multicolumn{2}{|c|}{$\mathrm{L}_{2}$} & \multicolumn{2}{|c|}{$\mathrm{L}_{3}$} & \multirow[t]{2}{*}{ Mean } & \multicolumn{2}{|c|}{$\mathrm{L}_{1}$} & \multicolumn{2}{|c|}{$\mathrm{L}_{2}$} & \multicolumn{2}{|c|}{$\mathrm{L}_{3}$} & \multirow[t]{2}{*}{ Mean } \\
\hline & $\mathrm{H}_{1}$ & $\mathrm{H}_{2}$ & $\mathrm{H}_{1}$ & $\mathrm{H}_{2}$ & $\mathrm{H}_{1}$ & $\mathrm{H}_{2}$ & & $\mathrm{H}_{1}$ & $\mathrm{H}_{2}$ & $\mathrm{H}_{1}$ & $\mathrm{H}_{2}$ & $\mathrm{H}_{1}$ & $\mathrm{H}_{2}$ & \\
\hline G.84-47 & 305.3 & 307.7 & 329.3 & 331.0 & 298.0 & 300.3 & 311.9 & 304.3 & 305.0 & 314.0 & 315.0 & 284.7 & 286.0 & 301.5 \\
\hline G.99-103 & 325.3 & 335.0 & 315.0 & 321.0 & 271.0 & 277.0 & 307.4 & 319.3 & 321.0 & 300.7 & 305.0 & 270.0 & 274.0 & 298.3 \\
\hline G.2003-44 & 313.7 & 316.3 & 297.3 & 300.3 & 274.3 & 276.7 & 296.4 & 292.7 & 295.0 & 301.0 & 301.7 & 295.0 & 296.7 & 297.0 \\
\hline G.2003-47 & 301.7 & 304.7 & 267.3 & 270.7 & 266.0 & 271.0 & 280.2 & 285.3 & 286.7 & 284.7 & 288.3 & 283.7 & 285.3 & 285.7 \\
\hline G.2003-49 & 305.7 & 305.7 & 287.7 & 292.3 & 258.3 & 262.0 & 285.3 & 287.7 & 290.0 & 290.7 & 293.3 & 258.0 & 260.0 & 279.9 \\
\hline G.2004-27 & 312.7 & 315.7 & 300.3 & 305.0 & 278.3 & 283.7 & 299.3 & 301.0 & 305.0 & 303.7 & 306.7 & 292.3 & 293.3 & 300.3 \\
\hline G.2007-61 & 303.0 & 304.3 & 286.3 & 287.7 & 264.0 & 223.0 & 278.1 & 274.7 & 276.7 & 293.3 & 293.7 & 253.0 & 254.0 & 274.2 \\
\hline G.2010-7 & 310.0 & 313.3 & 298.3 & 301.7 & 286.0 & 289.7 & 299.8 & 304.0 & 305.0 & 314.3 & 315.7 & 290.0 & 290.7 & 303.3 \\
\hline G.2010-26 & 275.0 & 276.0 & 266.0 & 270.0 & 188.7 & 193.3 & 244.8 & 234.7 & 238.3 & 262.3 & 263.3 & 145.0 & 145.3 & 214.8 \\
\hline G.2011-82 & 309.0 & 311.0 & 299.0 & 304.0 & 247.0 & 249.7 & 286.6 & 310.7 & 313.3 & 290.7 & 291.7 & 233.3 & 233.7 & 278.9 \\
\hline G.T.54-9 & 308.0 & 312.0 & 277.0 & 281.7 & 286.3 & 289.3 & 292.4 & 305.7 & 306.7 & 291.3 & 293.3 & 285.3 & 286.7 & 294.8 \\
\hline Average & 306.3 & 309.2 & 293.1 & 296.8 & 265.3 & 265.1 & 289.3 & 292.7 & 294.8 & 295.2 & 297.1 & 262.8 & 264.2 & 284.4 \\
\hline $\mathrm{RLSD}_{05}$ & & & & & & & 1.55 & & & & & & & 0.74 \\
\hline $\mathrm{RLSD}_{01}$ & & & & & & & 2.03 & & & & & & & 0.98 \\
\hline
\end{tabular}

$\mathrm{L}_{1}=$ Kom-Ombo $\quad \mathrm{L}_{2}=$ El-Mattana $\quad \mathrm{L}_{3}=$ Shandaweel $_{1}=$ early harvesting date $\mathrm{H}_{2}=$ late harvesting date. 
Ali et al., SVU-International Journal of Agricultural Sciences, 2 (2): 192-213, 2020

Table 4. Average performance of 11 genotypes in two seasons, at three locations and two harvesting dates for stalk weight.

\begin{tabular}{|c|c|c|c|c|c|c|c|c|c|c|c|c|c|c|}
\hline \multirow[t]{3}{*}{ Genotypes } & \multicolumn{7}{|c|}{ 2015/2016 (plant-cane) } & \multicolumn{7}{|c|}{ 2016/2017 (first-ratoon) } \\
\hline & \multicolumn{2}{|c|}{$\mathrm{L}_{1}$} & \multicolumn{2}{|c|}{$\mathrm{L}_{2}$} & \multicolumn{2}{|c|}{$\mathrm{L}_{3}$} & \multirow[t]{2}{*}{ Mean } & \multicolumn{2}{|c|}{$\mathrm{L}_{1}$} & \multicolumn{2}{|c|}{$\mathrm{L}_{2}$} & \multicolumn{2}{|c|}{$\mathrm{L}_{3}$} & \multirow[t]{2}{*}{ Mean } \\
\hline & $\mathrm{H}_{1}$ & $\mathrm{H}_{2}$ & $\mathrm{H}_{1}$ & $\mathrm{H}_{2}$ & $\mathrm{H}_{1}$ & $\mathrm{H}_{2}$ & & $\mathrm{H}_{1}$ & $\mathrm{H}_{2}$ & $\mathrm{H}_{1}$ & $\mathrm{H}_{2}$ & $\mathrm{H}_{1}$ & $\mathrm{H}_{2}$ & \\
\hline G.84-47 & 1.18 & 1.24 & 1.42 & 1.44 & 1.10 & 1.15 & 1.26 & 0.98 & 1.21 & 1.10 & 1.13 & 1.02 & 1.08 & 1.09 \\
\hline G.99-103 & 1.87 & 1.81 & 1.75 & 2.04 & 1.30 & 1.42 & 1.70 & 1.29 & 1.37 & 1.20 & 1.30 & 1.67 & 1.73 & 1.43 \\
\hline G.2003-44 & 1.19 & 1.24 & 1.45 & 1.48 & 0.96 & 1.04 & 1.23 & 1.00 & 1.22 & 0.89 & 0.94 & 1.02 & 1.13 & 1.03 \\
\hline G.2003-47 & 1.41 & 1.49 & 1.36 & 1.41 & 1.17 & 1.25 & 1.35 & 1.16 & 1.32 & 1.10 & 0.94 & 1.23 & 1.28 & 1.17 \\
\hline G.2003-49 & 1.48 & 1.52 & 1.24 & 1.32 & 1.07 & 1.18 & 1.30 & 0.95 & 1.27 & 1.02 & 1.04 & 1.23 & 1.31 & 1.14 \\
\hline G.2004-27 & 1.72 & 1.41 & 1.19 & 1.29 & 0.99 & 1.12 & 1.29 & 1.28 & 1.44 & 1.05 & 1.01 & 1.10 & 1.21 & 1.18 \\
\hline G.2007-61 & 1.21 & 1.23 & 1.42 & 1.43 & 0.92 & 0.94 & 1.19 & 1.05 & 1.34 & 0.83 & 0.80 & 1.10 & 1.21 & 1.06 \\
\hline G.2010-7 & 1.46 & 1.83 & 1.40 & 1.48 & 1.16 & 1.36 & 1.45 & 1.29 & 1.21 & 1.09 & 1.11 & 0.97 & 1.06 & 1.12 \\
\hline G.2010-26 & 1.09 & 1.20 & 1.28 & 1.39 & 0.90 & 1.19 & 1.17 & 1.07 & 1.32 & 1.16 & 1.07 & 0.63 & 0.65 & 0.98 \\
\hline G.2011-82 & 1.21 & 1.23 & 1.13 & 1.25 & 0.90 & 0.94 & 1.11 & 1.11 & 1.27 & 1.07 & 1.01 & 0.92 & 1.00 & 1.06 \\
\hline G.T.54-9 & 1.34 & 1.89 & 1.52 & 1.38 & 1.08 & 1.28 & 1.42 & 1.35 & 1.40 & 0.78 & 0.98 & 1.20 & 1.29 & 1.17 \\
\hline Average & 1.38 & 1.46 & 1.38 & 1.45 & 1.05 & 1.17 & 1.31 & 1.14 & 1.31 & 1.03 & 1.03 & 1.10 & 1.18 & 1.13 \\
\hline $\mathrm{RLSD}_{05}$ & & & & & & & 0.09 & & & & & & & 0.06 \\
\hline $\mathrm{RLSD}_{01}$ & & & & & & & 0.12 & & & & & & & 0.08 \\
\hline
\end{tabular}

$\mathrm{L}_{1}=$ Kom-Ombo $\quad \mathrm{L}_{2}=$ El-Mattana $\quad \mathrm{L}_{3}=$ ShandaweelH $\mathrm{H}_{1}=$ early harvesting date $\mathrm{H}_{2}=$ late harvesting date. 
Ali et al., SVU-International Journal of Agricultural Sciences, 2 (2): 192-213, 2020

Table 5. Average performance of 11 genotypes in two seasons, at three locations and two harvesting dates for cane yield.

\begin{tabular}{|c|c|c|c|c|c|c|c|c|c|c|c|c|c|c|}
\hline \multirow[t]{3}{*}{ Genotypes } & \multicolumn{7}{|c|}{ 2015/2016 (plant-cane) } & \multicolumn{7}{|c|}{ 2016/2017 (first-ratoon) } \\
\hline & \multicolumn{2}{|c|}{$\mathrm{L}_{1}$} & \multicolumn{2}{|c|}{$\mathrm{L}_{2}$} & \multicolumn{2}{|c|}{$\mathrm{L}_{3}$} & \multirow[t]{2}{*}{ Mean } & \multicolumn{2}{|c|}{$\mathrm{L}_{1}$} & \multicolumn{2}{|c|}{$\mathrm{L}_{2}$} & \multicolumn{2}{|c|}{$\mathrm{L}_{3}$} & \multirow[t]{2}{*}{ Mean } \\
\hline & $\mathrm{H}_{1}$ & $\mathrm{H}_{2}$ & $\mathrm{H}_{1}$ & $\mathrm{H}_{2}$ & $\mathrm{H}_{1}$ & $\mathrm{H}_{2}$ & & $\mathrm{H}_{1}$ & $\mathrm{H}_{2}$ & $\mathrm{H}_{1}$ & $\mathrm{H}_{2}$ & $\mathrm{H}_{1}$ & $\mathrm{H}_{2}$ & \\
\hline G.84-47 & 46.84 & 49.51 & 77.68 & 78.67 & 40.22 & 42.51 & 55.90 & 52.35 & 64.60 & 66.82 & 68.86 & 45.09 & 47.93 & 57.61 \\
\hline G.99-103 & 64.34 & 63.47 & 73.91 & 85.98 & 46.55 & 50.26 & 64.09 & 52.06 & 55.71 & 69.65 & 75.93 & 59.19 & 61.32 & 62.31 \\
\hline G.2003-44 & 48.66 & 51.65 & 69.11 & 70.32 & 32.49 & 34.53 & 51.13 & 47.91 & 58.52 & 50.85 & 53.78 & 42.52 & 46.88 & 50.08 \\
\hline G.2003-47 & 65.13 & 68.86 & 55.50 & 57.23 & 45.54 & 48.28 & 56.76 & 57.39 & 64.58 & 59.37 & 50.31 & 55.82 & 58.04 & 57.59 \\
\hline G.2003-49 & 65.85 & 67.84 & 48.78 & 49.11 & 48.30 & 53.19 & 55.51 & 47.43 & 63.50 & 45.98 & 46.73 & 55.76 & 59.35 & 53.13 \\
\hline G.2004-27 & 70.42 & 59.80 & 57.93 & 63.03 & 43.33 & 48.64 & 57.19 & 54.55 & 61.36 & 59.33 & 57.40 & 51.56 & 56.71 & 56.82 \\
\hline G.2007-61 & 65.49 & 66.61 & 57.02 & 57.14 & 48.22 & 49.27 & 57.29 & 62.20 & 79.75 & 42.86 & 42.45 & 54.49 & 60.05 & 56.97 \\
\hline G.2010-7 & 62.20 & 70.45 & 50.04 & 53.41 & 53.77 & 62.40 & 58.71 & 65.34 & 61.35 & 58.38 & 59.86 & 43.44 & 47.13 & 55.92 \\
\hline G.2010-26 & 49.78 & 54.69 & 44.36 & 48.14 & 39.36 & 51.77 & 48.02 & 40.84 & 50.49 & 47.79 & 44.52 & 26.73 & 27.60 & 39.66 \\
\hline G.2011-82 & 56.95 & 60.01 & 54.27 & 60.13 & 45.54 & 47.73 & 54.10 & 54.45 & 62.05 & 61.23 & 58.26 & 43.98 & 48.00 & 54.66 \\
\hline G.T.54-9 & 59.40 & 66.67 & 59.53 & 58.19 & 42.98 & 51.61 & 56.40 & 66.14 & 68.52 & 41.25 & 52.25 & 53.27 & 57.69 & 56.52 \\
\hline Average & 59.55 & 61.78 & 58.92 & 61.94 & 44.21 & 49.11 & 55.92 & 54.61 & 62.77 & 54.87 & 55.48 & 48.35 & 51.88 & 54.66 \\
\hline $\mathrm{RLSD}_{05}$ & & & & & & & 5.76 & & & & & & & 2.49 \\
\hline $\mathrm{RLSD}_{01}$ & & & & & & & 8.17 & & & & & & & 3.43 \\
\hline
\end{tabular}

$\mathrm{L}_{1}=$ Kom-Ombo $\quad \mathrm{L}_{2}=$ El-Mattana $\quad \mathrm{L}_{3}=$ ShandaweelH $\mathrm{H}_{1}=$ early harvesting date $\mathrm{H}_{2}=$ late harvesting date. 
Ali et al., SVU-International Journal of Agricultural Sciences, 2 (2): 192-213, 2020

Table 6. Average performance of 11 genotypes in two seasons, at three locations and two harvesting dates for brix.

\begin{tabular}{|c|c|c|c|c|c|c|c|c|c|c|c|c|c|c|}
\hline \multirow[t]{3}{*}{ Genotypes } & \multicolumn{7}{|c|}{ 2015/2016 (plant-cane) } & \multicolumn{7}{|c|}{ 2016/2017 (first-ratoon) } \\
\hline & \multicolumn{2}{|c|}{$\mathrm{L}_{1}$} & \multicolumn{2}{|c|}{$\mathrm{L}_{2}$} & \multicolumn{2}{|c|}{$\mathrm{L}_{3}$} & \multirow[t]{2}{*}{ Mean } & \multicolumn{2}{|c|}{$\mathrm{L}_{1}$} & \multicolumn{2}{|c|}{$\mathrm{L}_{2}$} & \multicolumn{2}{|c|}{$\mathrm{L}_{3}$} & \multirow{2}{*}{ Mean } \\
\hline & $\mathrm{H}_{1}$ & $\mathrm{H}_{2}$ & $\mathrm{H}_{1}$ & $\mathrm{H}_{2}$ & $\mathrm{H}_{1}$ & $\mathrm{H}_{2}$ & & $\mathrm{H}_{1}$ & $\mathrm{H}_{2}$ & $\mathrm{H}_{1}$ & $\mathrm{H}_{2}$ & $\mathrm{H}_{1}$ & $\mathrm{H}_{2}$ & \\
\hline G. $84-47$ & 19.62 & 22.01 & 18.33 & 20.57 & 20.80 & 21.99 & 20.55 & 22.00 & 23.50 & 18.87 & 22.13 & 20.19 & 21.95 & 21.44 \\
\hline G.99-103 & 18.03 & 19.50 & 17.13 & 18.57 & 18.24 & 20.40 & 18.65 & 18.67 & 21.05 & 18.63 & 20.47 & 19.83 & 21.46 & 20.02 \\
\hline G.2003-44 & 19.56 & 21.13 & 19.17 & 19.70 & 20.13 & 21.11 & 20.13 & 22.50 & 21.41 & 20.07 & 20.37 & 20.84 & 21.27 & 21.08 \\
\hline G.2003-47 & 20.56 & 21.84 & 19.27 & 19.97 & 20.15 & 22.32 & 20.68 & 21.86 & 23.13 & 20.07 & 21.83 & 21.83 & 22.87 & 21.93 \\
\hline G.2003-49 & 20.26 & 21.73 & 19.00 & 19.13 & 19.67 & 21.75 & 20.26 & 21.83 & 22.61 & 19.90 & 21.00 & 22.11 & 22.91 & 21.73 \\
\hline G.2004-27 & 20.08 & 19.89 & 17.33 & 19.50 & 18.71 & 21.27 & 19.46 & 21.05 & 22.13 & 18.77 & 21.67 & 19.07 & 20.50 & 20.53 \\
\hline G.2007-61 & 19.70 & 21.32 & 18.13 & 19.70 & 20.80 & 21.36 & 20.17 & 20.49 & 22.13 & 19.60 & 19.93 & 21.59 & 22.39 & 21.02 \\
\hline G.2010-7 & 16.72 & 19.31 & 17.13 & 17.23 & 17.70 & 18.95 & 17.84 & 18.13 & 19.33 & 19.93 & 20.57 & 18.73 & 19.27 & 19.33 \\
\hline G.2010-26 & 20.06 & 20.70 & 18.97 & 19.37 & 20.23 & 22.44 & 20.29 & 21.22 & 21.99 & 19.77 & 21.13 & 21.91 & 22.48 & 21.42 \\
\hline G.2011-82 & 19.81 & 21.31 & 17.23 & 20.20 & 20.62 & 22.01 & 20.20 & 20.85 & 23.45 & 18.57 & 21.33 & 21.48 & 22.96 & 21.44 \\
\hline G.T.54-9 & 19.71 & 20.20 & 16.57 & 17.23 & 19.61 & 21.30 & 19.10 & 20.64 & 21.21 & 19.40 & 21.73 & 20.99 & 22.05 & 21.01 \\
\hline Average & 19.46 & 20.81 & 18.02 & 19.20 & 19.70 & 21.35 & 19.76 & 20.84 & 22.00 & 19.42 & 21.11 & 20.78 & 21.83 & 20.99 \\
\hline RLSD $_{05}$ & & & & & & & 0.43 & & & & & & & 0.31 \\
\hline RLSD $_{01}$ & & & & & & & 0.59 & & & & & & & 0.43 \\
\hline
\end{tabular}

$\mathrm{L}_{1}=$ Kom-Ombo $\quad \mathrm{L}_{2}=$ El-Mattana $\quad \mathrm{L}_{3}=$ ShandaweelH $\mathrm{H}_{1}=$ early harvesting date $\mathrm{H}_{2}=$ late harvesting date. 
Ali et al., SVU-International Journal of Agricultural Sciences, 2 (2): 192-213, 2020

Table 7. Average performance of 11 genotypes in two seasons, at three locations and two harvesting dates for sucrose.

\begin{tabular}{|c|c|c|c|c|c|c|c|c|c|c|c|c|c|c|}
\hline \multirow[t]{3}{*}{ Genotypes } & \multicolumn{7}{|c|}{ 2015/2016 (plant-cane) } & \multicolumn{7}{|c|}{ 2016/2017 (first-ratoon) } \\
\hline & \multicolumn{2}{|c|}{$\mathrm{L}_{1}$} & \multicolumn{2}{|c|}{$\mathrm{L}_{2}$} & \multicolumn{2}{|c|}{$\mathrm{L}_{3}$} & \multirow[t]{2}{*}{ Mean } & \multicolumn{2}{|c|}{$\mathrm{L}_{1}$} & \multicolumn{2}{|c|}{$\mathrm{L}_{2}$} & \multicolumn{2}{|c|}{$\mathrm{L}_{3}$} & \multirow[t]{2}{*}{ Mean } \\
\hline & $\mathrm{H}_{1}$ & $\mathrm{H}_{2}$ & $\mathrm{H}_{1}$ & $\mathrm{H}_{2}$ & $\mathrm{H}_{1}$ & $\mathrm{H}_{2}$ & & $\mathrm{H}_{1}$ & $\mathrm{H}_{2}$ & $\mathrm{H}_{1}$ & $\mathrm{H}_{2}$ & $\mathrm{H}_{1}$ & $\mathrm{H}_{2}$ & \\
\hline G.84-47 & 16.88 & 18.83 & 16.30 & 18.10 & 17.04 & 18.24 & 17.57 & 18.60 & 21.21 & 13.66 & 18.30 & 15.55 & 17.12 & 17.41 \\
\hline G.99-103 & 15.67 & 16.99 & 14.62 & 15.37 & 14.76 & 16.87 & 15.71 & 15.87 & 18.00 & 14.11 & 16.74 & 16.19 & 17.62 & 16.42 \\
\hline G.2003-44 & 17.49 & 18.46 & 15.84 & 16.37 & 17.26 & 17.65 & 17.18 & 19.29 & 18.88 & 16.57 & 16.75 & 17.61 & 17.91 & 17.84 \\
\hline G.2003-47 & 18.09 & 19.47 & 17.15 & 16.05 & 17.92 & 18.88 & 17.93 & 19.75 & 20.62 & 16.39 & 19.23 & 18.57 & 19.58 & 19.02 \\
\hline G.2003-49 & 18.03 & 19.31 & 16.54 & 16.10 & 16.70 & 18.34 & 17.50 & 19.17 & 19.96 & 16.32 & 18.65 & 20.02 & 20.92 & 19.17 \\
\hline G.2004-27 & 17.52 & 16.65 & 13.81 & 16.63 & 14.91 & 17.22 & 16.12 & 18.03 & 18.61 & 14.26 & 16.73 & 14.94 & 16.46 & 16.50 \\
\hline G.2007-61 & 16.94 & 17.51 & 15.19 & 16.38 & 18.19 & 17.76 & 17.00 & 17.78 & 19.41 & 14.07 & 16.13 & 17.89 & 18.58 & 17.31 \\
\hline G.2010-7 & 13.39 & 16.22 & 13.46 & 13.69 & 13.96 & 14.30 & 14.17 & 14.90 & 16.64 & 16.54 & 17.27 & 14.81 & 15.25 & 15.90 \\
\hline G.2010-26 & 17.24 & 17.83 & 16.13 & 14.89 & 17.06 & 18.95 & 17.02 & 18.19 & 19.13 & 15.35 & 17.49 & 17.40 & 18.15 & 17.62 \\
\hline G.2011-82 & 16.98 & 18.43 & 14.04 & 15.50 & 16.87 & 18.15 & 16.66 & 18.11 & 21.21 & 14.19 & 17.38 & 17.59 & 18.94 & 17.91 \\
\hline G.T.54-9 & 17.01 & 17.74 & 13.81 & 14.07 & 16.13 & 17.71 & 16.08 & 18.32 & 18.71 & 15.10 & 18.85 & 17.60 & 18.64 & 17.87 \\
\hline Average & 16.84 & 17.95 & 15.17 & 15.74 & 16.44 & 17.64 & 16.63 & 18.00 & 19.31 & 15.14 & 17.59 & 17.10 & 18.11 & 17.54 \\
\hline $\mathrm{RLSD}_{05}$ & & & & & & & 0.59 & & & & & & & 0.43 \\
\hline $\mathrm{RLSD}_{01}$ & & & & & & & 0.81 & & & & & & & 0.59 \\
\hline
\end{tabular}

$\mathrm{L}_{1}=$ Kom-Ombo $\quad \mathrm{L}_{2}=$ El-Mattana $\quad \mathrm{L}_{3}=$ Shandaweel $\mathrm{H}_{1}=$ early harvesting date $\mathrm{H}_{2}=$ late harvesting date. 
Ali et al., SVU-International Journal of Agricultural Sciences, 2 (2): 192-213, 2020

Table 8. Average performance of 11 genotypes in two seasons, at three locations and two harvesting dates for sugar yield.

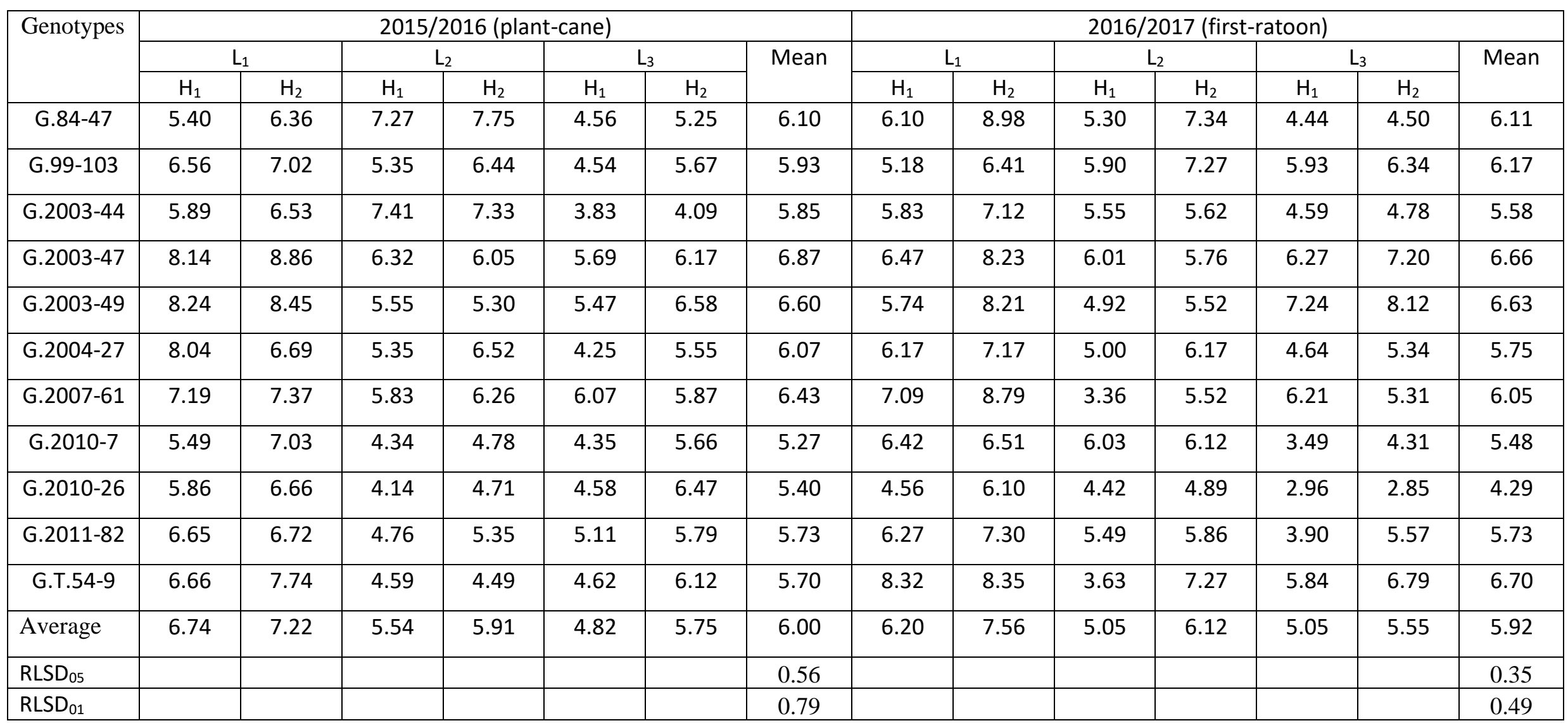

$\mathrm{L}_{1}=$ Kom-Ombo $\quad \mathrm{L}_{2}=$ El-Mattana $\quad \mathrm{L}_{3}=$ Shandaweel $\mathrm{H}_{1}=$ early harvesting date $\mathrm{H}_{2}=$ late harvesting date. 
significant for these traits. In addition, partitions of the genotypes $\times$ environments interaction to Env. $+(\mathrm{G} \times$ Env. $)$, Env. (Linear) and genotype $\times$ environment (Linear) were significant and highly significant. Therefore, the stability analysis was performed according to Eberhart\& Russell (1966). This indicates that the change in the performance of a genotype fromone location to another or genotypes showed different responses in yield and its components when growing in different environments.

\section{b1- Stalk length}

Concerning stalk length, it noticed that the genotype G.2003-49 was stable because the regression coefficient (bi) was insignificant from unity and the deviation from regression (S2di) was insignificant from zero. The remainder genotypes were unstable and gave highly significant S2di, irrespective of the two genotypes, which showed regression coefficients, which did not differ significantly from unit slope (Table 10 and Fig. 1). Tahir et al. (2013) showed that all genotypes were unstable overall environments for plant height.

\section{b2-Stalk weight}

Considering stalk weight, six genotypes (G.2003-44, G.2003-47, G.2003-49, G.200427, G.2007-61 and G.2011-82) were stable (Table 10 and Fig. 2). Three of them (G.200347, G.2004-27 and G.2011-82) were also stable for cane yield. The stable genotypes ranged from 1.09 to $1.26 \mathrm{~kg}$. According to Eberhart \& Russell (1966) the genotype G.2004-27 considered to be superior because the regression coefficient of this genotype equal one $($ bi $=1)$, the deviation from regression (S2di) was insignificant from zero and it had a high mean of performance when compared with the mean overall genotypes. Moreover, three of them (G.2003-47, G.2003-49 and G.2011-82) performed consistently better in unfavorable environments because the regression coefficient (bi) was less than one. Means of stalk weight ranged from 1.08 to $1.56 \mathrm{~kg}$ (Table 10 and Fig. 1). The other genotypes were unstable (S2di gave highly significant from zero). These results are in line with those reported by Guddadamath et al. (2014) and Dubey et al. (2017).

Table 9. Analysis of variance of 11 genotypes for the studied traits overall environments.

\begin{tabular}{|c|c|c|c|c|c|c|c|}
\hline \multirow[b]{2}{*}{ S. O. V } & \multirow[b]{2}{*}{$\mathrm{df}$} & \multicolumn{6}{|c|}{ Mean squares } \\
\hline & & $\begin{array}{l}\text { Stalk } \\
\text { length } \\
(\mathrm{cm})\end{array}$ & $\begin{array}{c}\text { Stalk } \\
\text { weight } \\
(\mathrm{kg})\end{array}$ & $\begin{array}{c}\text { Cane yield } \\
(\mathrm{t} / \mathrm{fed})\end{array}$ & Brix (\%) & $\begin{array}{c}\text { Sucrose } \\
(\%)\end{array}$ & $\begin{array}{l}\text { Sugar } \\
\text { yield } \\
\text { (t/fed) }\end{array}$ \\
\hline Genotypes (G) & 10 & $5513.028^{* *}$ & $0.230^{* *}$ & $194.79^{* *}$ & $8.05^{* *}$ & $11.73^{* *}$ & $2.77^{* *}$ \\
\hline Env.+ $(\mathrm{G} \times$ Env. $)$ & 121 & $527.702^{* *}$ & $0.050^{* *}$ & $65.15^{* *}$ & $1.88^{* *}$ & $2.37^{* *}$ & $1.93^{* *}$ \\
\hline Env. (Linear) & 1 & $36576.37^{* *}$ & $3.667^{* *}$ & $3171.67^{* *}$ & $175.24^{* *}$ & $196.57^{* *}$ & $129.82^{\text {*** }}$ \\
\hline $\mathrm{G} \times$ Env. (Linear) & 10 & $1686.76^{* *}$ & $0.039^{* *}$ & $76.50^{*}$ & $0.84^{* *}$ & $1.45^{* *}$ & $1.66^{* *}$ \\
\hline Pooled deviation & 110 & $94.62^{* *}$ & $0.019^{* *}$ & $35.88^{* *}$ & $0.40^{* *}$ & $0.69^{* *}$ & $0.79^{* *}$ \\
\hline Pooled error & 240 & 5.28 & 0.006 & 7.85 & 0.12 & 0.22 & 0.19 \\
\hline
\end{tabular}

*, ** Significant at 0.05 and 0.01 probability levels, respectively.

\section{b3- Cane yield}

The stability parameters (Table 10 and Fig. 3 ) showed that the genotypes varied in their bi values as well as S2di. It noticed that the intermediate yielding genotypes (G.2003-47,
G.2004-27 and G.2011-82) were stable and ranged in cane yield from 54.38 to $57.17 \mathrm{t} /$ fed. According to Eberhart \& Russell (1966) the genotype G.2004-27 considered to be superior 
Ali et al., SVU-International Journal of Agricultural Sciences, 2 (2): 192-213, 2020

Table 10. Stability parameters for stalk length stalk weight and cane yield of 11 genotypes over 12 environments.

\begin{tabular}{|l|l|l|l|l|l|c|c|c|c|c|}
\hline \multirow{2}{*}{ No. } & \multirow{2}{*}{ Pedigree } & \multicolumn{3}{|c|}{ Stalk length } & \multicolumn{3}{c|}{ Stalk weight } & \multicolumn{3}{c|}{ Cane yield } \\
\cline { 3 - 11 } & & Means $(\bar{X})$ & $b_{i}$ & $S^{2} d$ & Means $(\bar{X})$ & $b_{i}$ & $S^{2} d$ & Means $(\bar{X})$ & $b_{i}$ & $S^{2} d$ \\
\hline 1 & G.84-47 & 306.7 & $0.55^{* *}$ & $121.34^{* *}$ & 1.17 & $0.47^{* *}$ & $0.015^{* *}$ & 56.76 & 1.45 & $117.41^{* *}$ \\
\hline 2 & G.99-103 & 302.9 & 1.31 & $46.21^{* *}$ & 1.56 & 1.46 & $0.027^{* *}$ & 63.20 & 1.13 & $89.86^{* *}$ \\
\hline 3 & G.2003-44 & 296.7 & $0.45^{* *}$ & $60.48^{* *}$ & 1.13 & 1.05 & 0.008 & 50.60 & 1.59 & $40.75^{* *}$ \\
\hline 4 & G.2003-47 & 282.9 & $0.39^{* *}$ & $114.49^{* *}$ & 1.26 & 0.82 & 0.003 & 57.17 & 0.88 & 14.28 \\
\hline 5 & G.2003-49 & 282.6 & 1.03 & -3.15 & 1.22 & 0.83 & 0.007 & 54.32 & 0.52 & $51.34^{* *}$ \\
\hline 6 & G.2004-27 & 299.8 & $0.59^{*}$ & $15.42^{* *}$ & 1.23 & 1.01 & 0.009 & 57.01 & 1.00 & 7.05 \\
\hline 7 & G.2007-61 & 276.1 & 1.24 & $117.40^{* *}$ & 1.12 & 1.07 & 0.009 & 57.13 & 1.07 & $74.51^{* *}$ \\
\hline 8 & G.2010-7 & 301.6 & $0.55^{* *}$ & $18.57^{* *}$ & 1.29 & 1.37 & $0.028^{* *}$ & 57.32 & 0.55 & $48.96^{* *}$ \\
\hline 9 & G.2010-26 & 229.8 & $2.67^{* *}$ & $290.01^{* *}$ & 1.08 & 0.77 & $0.022^{* *}$ & 43.84 & 0.89 & $48.97^{* *}$ \\
\hline 10 & G.2011-82 & 282.8 & $1.75^{* *}$ & $105.37^{* *}$ & 1.09 & 0.64 & 0.001 & 54.38 & 0.95 & 3.19 \\
\hline 11 & G.T.54-9 & 293.6 & $0.37^{* *}$ & $96.57^{* *}$ & 1.29 & $1.52^{* *}$ & $0.015^{* *}$ & 56.46 & 0.98 & $37.10^{* *}$ \\
\hline Mean & & 286.9 & - & - & 1.22 & - & - & 55.29 & - & - \\
\hline R. L. S. D. 0.05 & 30.12 & - & - & 0.06 & - & - & 2.46 & - & - \\
\hline R. L. S. D. 0.01 & 41.16 & - & - & 0.09 & - & - & 3.49 & - & - \\
\hline
\end{tabular}

*, ** Significantly from unity for (bi) and from zero for (S2d) at 0.05 and 0.01 probability levels, rspectively 
because the regression coefficient of this genotype equal one (bi = 1), the deviation from regression (S2di) was insignificant from zero and a high mean when compared with the mean over all genotypes. The genotype G.2003-47 was relatively better in unfavorable environments because the regression coefficient (bi) was less than one (Table 10 and Fig. 3). The other genotypes were unstable (S2di gave highly significant from zero). Similar results obtained by Bissessur et al. (2001), , Jun et al. (2009), Rea et al. (2011), Tiawari et al. (2011), Dutra et al. (2014), Jun et al. (2014), Rea et al. (2015), Anand et al. (2016) and Prema et al. (2017). Klomsa et al. (2013) noticed that the genotype K88-92 was the most superior genotype in cane yield. Alida et al. (2013) obtained three varieties; V98-62, V99- 236 and V00-50 were the most promising ones in all four agro-ecological zones. These sugarcane varieties were excellent yield potential, adaptation, and stability in different environments tested. Imtiaz et al. (2013) indicated that the clone NIA0819/P5 produced maximum stable cane yield and sugar yield compared to the commercial varieties. Otieno (2016) indicated that the five from 33 cultivars were considered ideal cultivars where exhibited stable and high yielding.

\section{b4-Brix:}

The results of brix (Table 11 and Fig. 4) exhibited that the four genotypes (G.99-103, G.2003-47, G.2003-49 and G.2010-26) were stable because these genotype shave regression coefficient (bi) which are not different from the unit slope and have S2di, which are not significantly different from zero. The stable genotypes ranged in percentage of brix from 19.33 to $21.33 \%$. According to Eberhart \& Russell (1966) two genotypes (G.2003-47 and G.2003-49) considered to be superior because the regression coefficient of these genotypes equal one (bi $=1)$, the deviation from regression (S2di) was insignificant from zero and had a high mean percentage of brix when compared with the mean overall genotypes. The genotype G.2010-26 performed consistently less in favorable environments (bi< 1.0). The genotype G.2003-47 was also stable for cane yield (Table 11 and Fig. 4). The other genotypes were unstable and gave highly significant S2di, irrespective of the four genotypes that showed regression coefficient, which did not differ significantly from unit slope (Table 11 and Fig. 4).These results are in accordance with those reported by Irlane et al. (2009)

\section{b5-Sucrose:}

As shown in Table 11 and Fig. 5, the regression coefficient (bi) for five genotypes (G.T.54-9, G.99-103, G.2003-44, G.2003-47 and G.2010-26) were insignificant from unity and the deviation from regression (S2di) were also insignificant from zero. This indicates that these genotypes considered being stable for such trait. The stable genotypes ranged in sucrose from 16.07 to $18.48 \%$ for sucrose. According to Eberhart \& Russell (1966) the genotype (G.2003-47) considered to be superior because the regression coefficient of this genotype equal one (bi $=1)$, the deviation from regression (S2di) was insignificant from zero and had a high mean percentage of sucrose when compared with the mean over all genotypes. This genotype was also stable for cane yield. However, two genotypes (G.200344 and G.2010-26) performed consistently less in favourable environments (bi< 1.0) (Table 11 and Fig. 2). The other genotypes were unstable (S2di significantly different from zero) (Table 11 and Fig. 5). Similar results obtained by Bissessur et al. (2001), Jun et al. (2009), Rea et al. (2011), Tiawari et al. (2011), Imtiaz et al. (2013), Guddadamath et al. (2014) and Rajesh and Sinha (2015). 


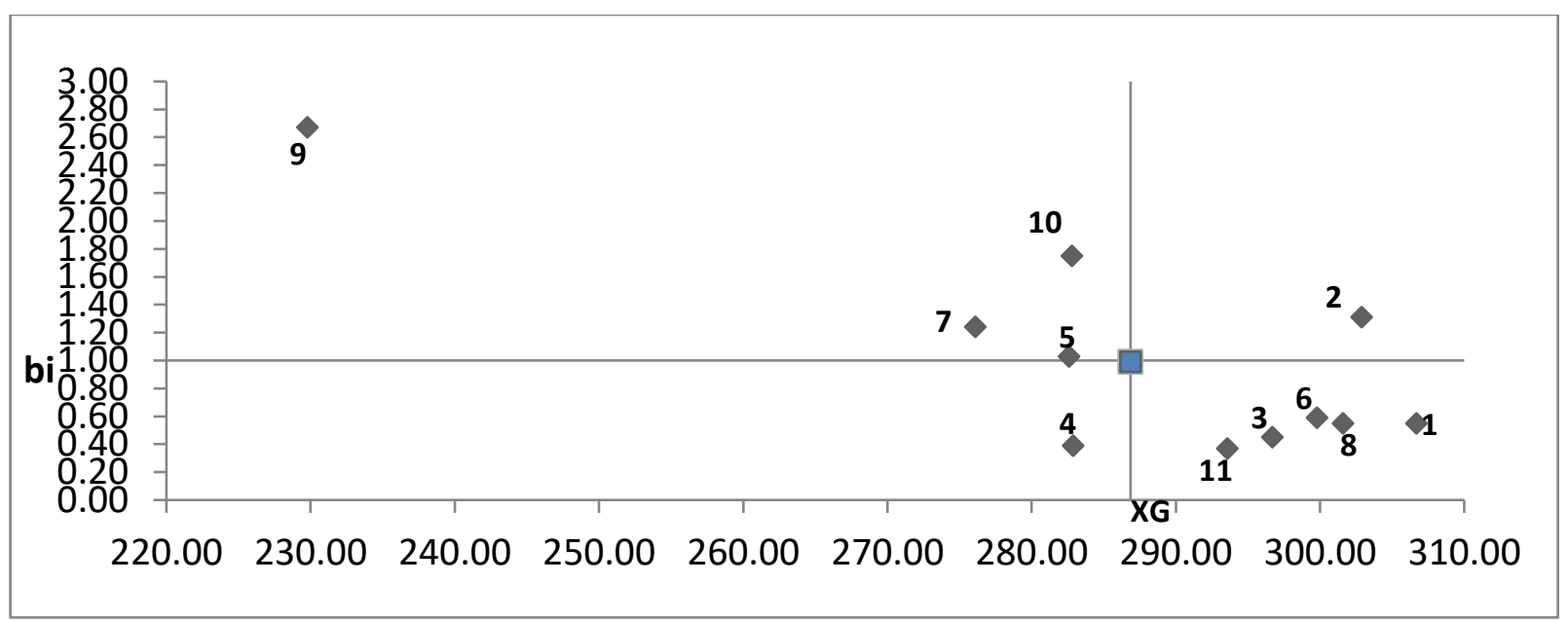

Fig. 1. Graphical illustration of the stability parameter $\left(b_{i}\right)$ and the mean performance of individual genotypes $(\overline{\mathrm{X}})$ for stalk length.

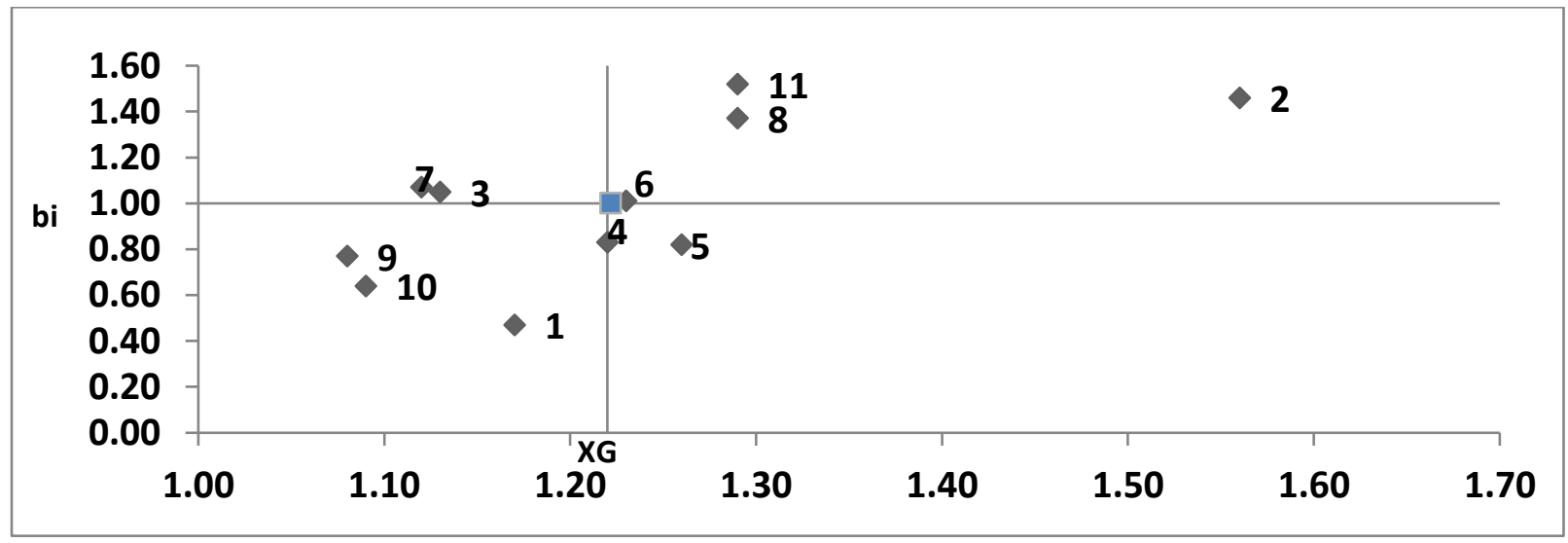

Fig. 2. Graphical illustration of the stability parameter (bi) and the mean performance of individual genotypes $(\overline{\mathrm{X}})$ for stalk weight.

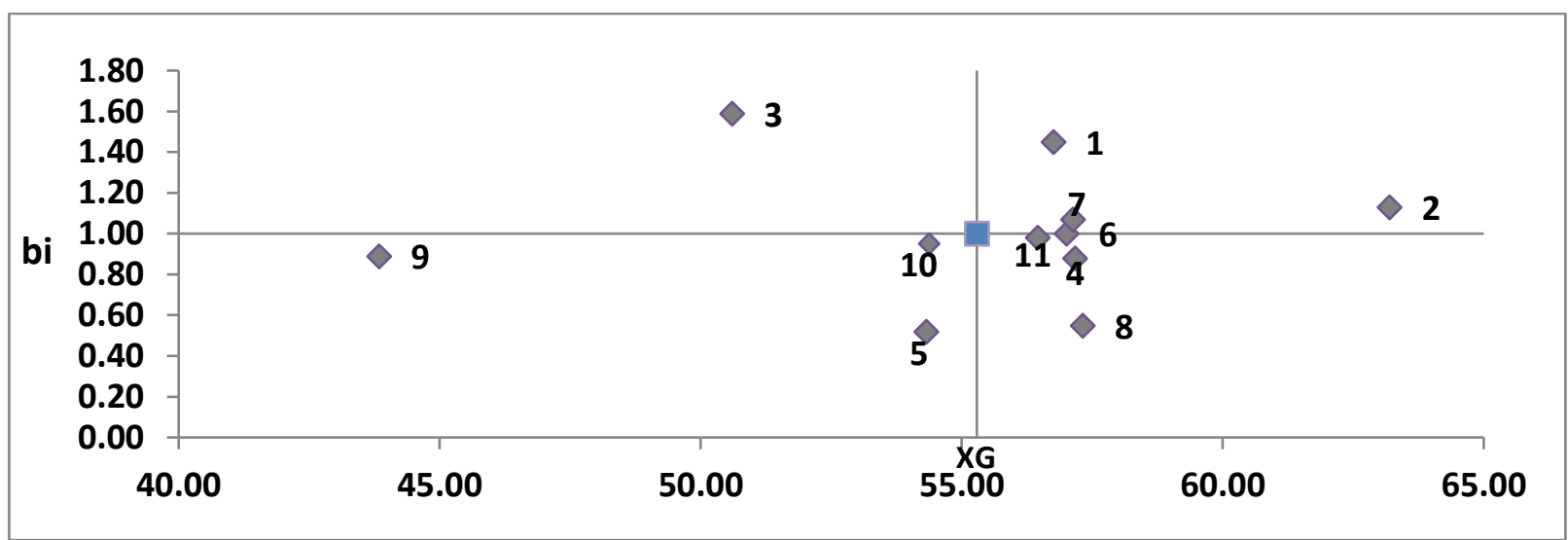

Fig. 3. Graphical illustration of the stability parameter (bi) and the mean performance of individual genotypes $(\overline{\mathrm{X}})$ for cane yield. 
Ali et al., SVU-International Journal of Agricultural Sciences, 2 (2): 192-213, 2020

Table 11. Stability parameters for brix, sucrose and sugar yield of 11 genotypes over 12 environments.

\begin{tabular}{|c|c|c|c|c|c|c|c|c|c|c|}
\hline \multirow[t]{2}{*}{ No. } & \multirow[t]{2}{*}{ Pedigree } & \multicolumn{3}{|c|}{ Brix } & \multicolumn{3}{|c|}{ Sucrose } & \multicolumn{3}{|c|}{ Sugar yield } \\
\hline & & $\begin{array}{c}\text { Means } \\
(\bar{X})\end{array}$ & $b_{i}$ & $S^{2} d$ & $\begin{array}{l}\text { Means } \\
(\bar{X})\end{array}$ & bi & $\mathrm{S}^{2} \mathrm{~d}$ & $\begin{array}{c}\text { Means } \\
(\bar{X})\end{array}$ & $b_{i}$ & $\mathrm{~S}^{2} \mathrm{~d}$ \\
\hline 1 & G.84-47 & 21.00 & 1.13 & $0.430 * *$ & 17.49 & 1.13 & $1.40 * *$ & 6.10 & 1.22 & $1.18 * *$ \\
\hline 2 & G.99-103 & 19.33 & 1.03 & 0.136 & 16.07 & 0.88 & 0.04 & 6.05 & $0.45^{* *}$ & 0.25 \\
\hline 3 & G.2003-44 & 20.60 & $0.63 *$ & $0.230 *$ & 17.51 & 0.69 & 0.10 & 5.71 & 0.62 & $1.02 * *$ \\
\hline 4 & G.2003-47 & 21.31 & 1.03 & -0.063 & 18.48 & 1.05 & -0.04 & 6.76 & 0.65 & $0.40^{*}$ \\
\hline 5 & G.2003-49 & 20.99 & 1.06 & 0.134 & 18.34 & 1.09 & $0.54 * *$ & 6.61 & 0.61 & $1.10 * *$ \\
\hline 6 & G.2004-27 & 20.00 & 0.98 & $0.533 * *$ & 16.31 & 0.94 & $0.73 * *$ & 5.91 & 1.17 & -0.04 \\
\hline 7 & G.2007-61 & 20.60 & 0.91 & $0.242 *$ & 17.15 & 0.97 & $0.56 * *$ & 6.24 & $1.68 * *$ & $0.48 * *$ \\
\hline 8 & G.2010-7 & 18.58 & 0.64* & $0.813 * *$ & 15.04 & $0.47 * *$ & $1.39 * *$ & 5.38 & 1.03 & $0.37 *$ \\
\hline 9 & G.2010-26 & 20.86 & 0.93 & 0.069 & 17.32 & 0.93 & 0.12 & 4.85 & 1.09 & $0.67 * *$ \\
\hline 10 & G.2011-82 & 20.82 & $1.37 *$ & $0.224 *$ & 17.28 & $1.55^{* *}$ & -0.05 & 5.73 & 1.19 & 0.16 \\
\hline 11 & G.T.54-9 & 20.05 & 1.30 & $0.369 * *$ & 16.97 & 1.29 & 0.36 & 6.20 & 1.30 & $1.05 * *$ \\
\hline \multicolumn{2}{|c|}{ Mean } & 20.38 & - & - & 17.09 & - & - & 5.96 & - & - \\
\hline \multicolumn{2}{|c|}{ R. L. S. D. 0.05} & 0.0 .51 & - & - & 0.39 & - & - & 0.89 & - & - \\
\hline \multicolumn{2}{|c|}{ R. L. S. D. 0.01} & 0.70 & - & - & 0.55 & - & - & 1.31 & - & - \\
\hline
\end{tabular}

*, ** Significantly from unity for $\left(b_{i}\right)$ and from zero for $\left(\mathrm{S}^{2} \mathrm{~d}\right)$ at 0.05 and 0.01 probability levels, respectively 


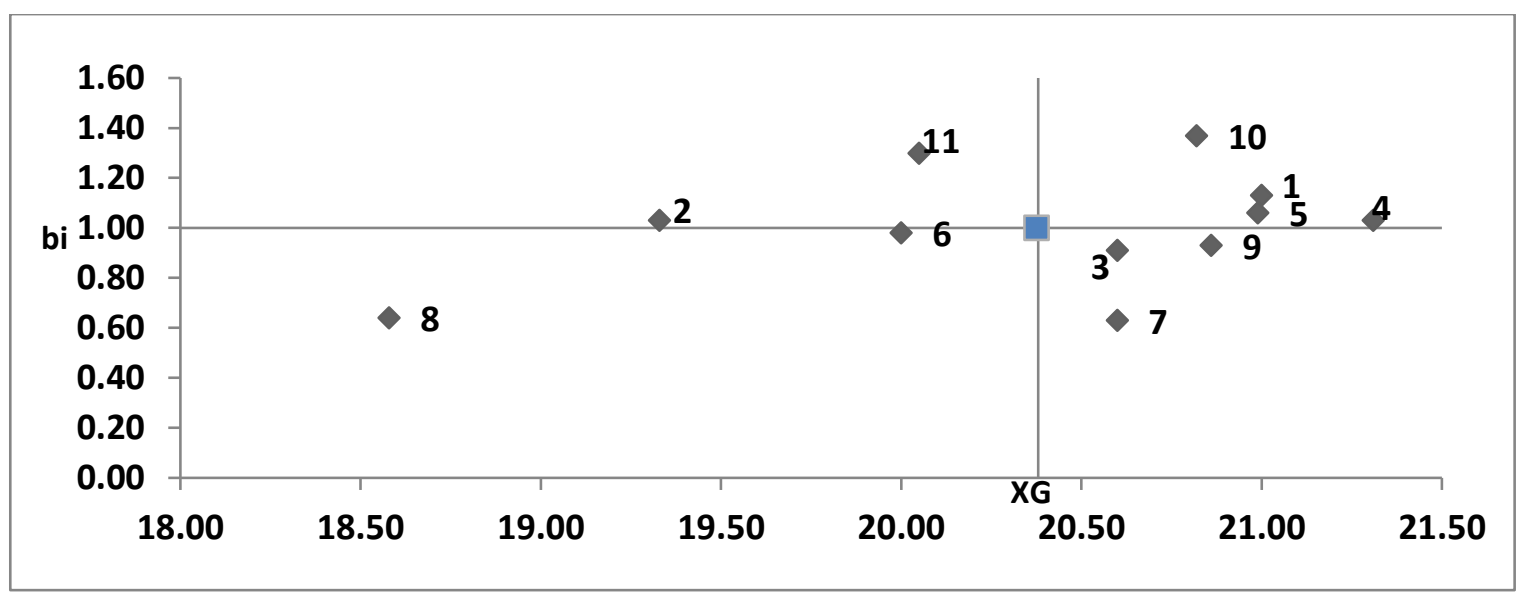

Fig. 4. Graphical illustration of the stability parameter (bi) and the mean performance of individual genotypes $(\overline{\mathrm{X}})$ for brix.

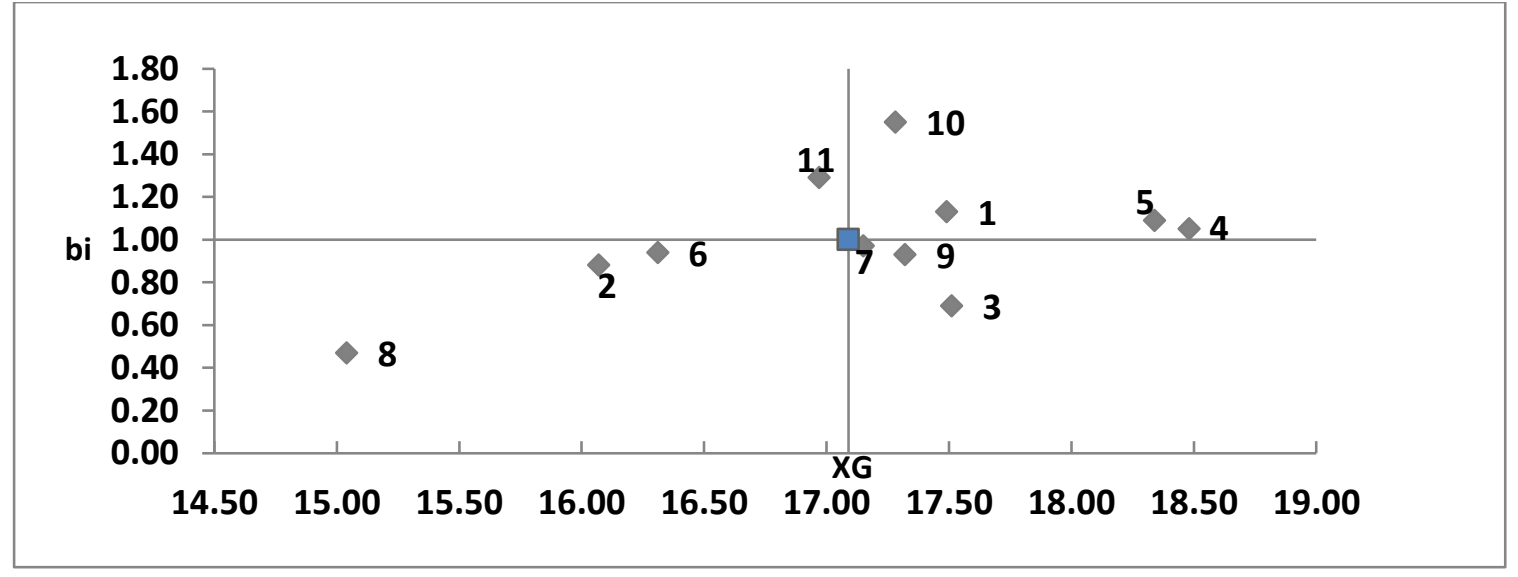

Fig. 5. Graphical illustration of the stability parameter (bi) and the mean performance of individual genotypes $(\bar{X})$ for sucrose.

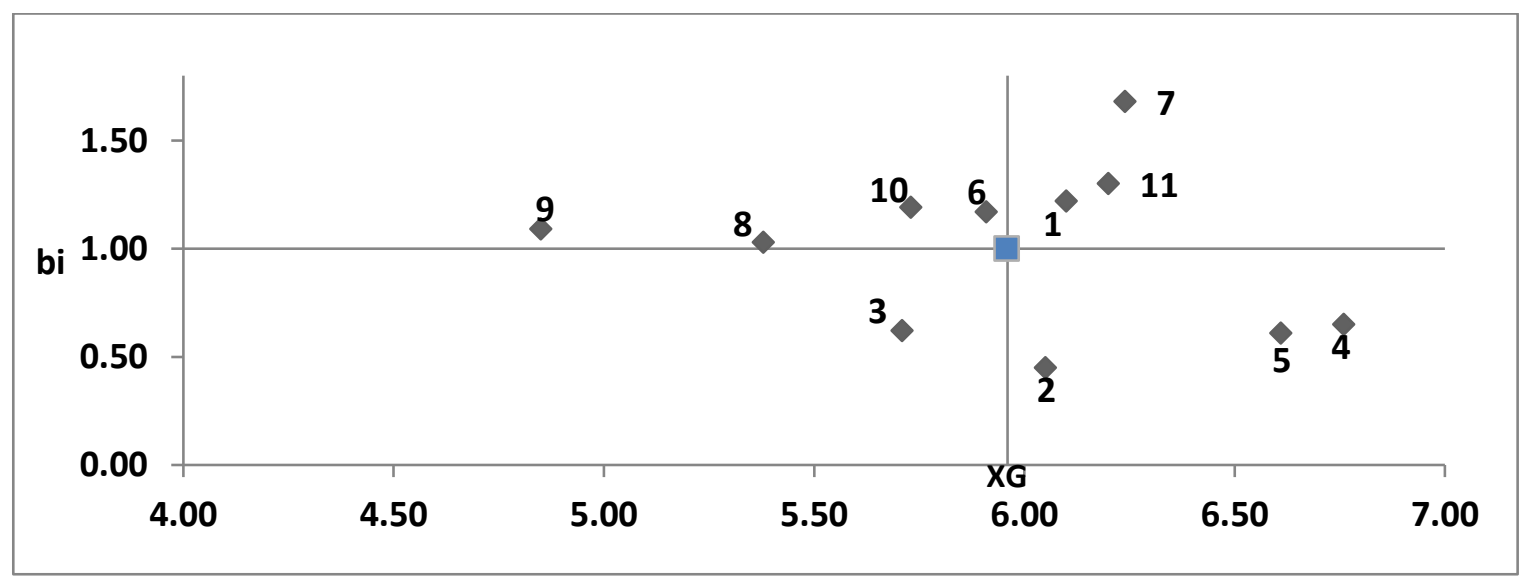

Fig. 6. Graphical illustration of the stability parameter (bi) and the mean performance of individual genotypes $(\bar{X}$ ) for sugar yield 


\section{b6- Sugar yield}

Regard to sugar yield (Table 11 and Fig. 6), the two of the studied genotypes (G.2004-27 and G.2011-82) were stable (bi and S2di not significantly differed from unit and zero, respectively). These genotypes were also stable for cane yield. The remainder genotypes were unstable and gave highly significant S2di.The sugar yield ranged from 4.85 to 6.76 ton/fed. Similar results obtained by Bissessur et al. (2001), Dutra et al. (2014), Jun et al. (2014), Sujeet et al. (2017), Prema et al. (2017), Muhammad et al. (2018) and Esayas et al. (2019).

\section{Conclusions}

In conclusion, these results showed that delaying harvesting date increased cane yield; stalk length, stalk weight, brix, sucrose and sugar yield. However, the intermediate yielding genotypes (G.2003-47, G.2004-27 and G.201182 ) were more stable than the rather responsive high yielding ones. Moreover, the genotype $\mathrm{G}$. 2004-27 was stable for cane yield and its components. In addition, it was considered to be superior for cane yield under different environments. However, it could be said the highest yielding ability genotype (G.99-103) at different environments was unstable. This could be due to the wide differences in both edaphic and climatic conditions prevailed at the three locations of the experiment. However, the unstable high yielding genotype G.99-103 still have higher yield compared to the other stable genotypes under the three locations. This indicates that stability analysis alone is not enough to decide on which genotypes to be recommended in certain locations without considering the average performance of such genotypes. Thus the genotype G.99-103 could be recommended to be grown in the locations under investigations.

\section{References}

Abd El-Razek A. M. and Bekheit S.Y. (2012)

'Effect of genotype, environment and time of harvest on sugarcane yields at middle and Upper Egypt' J. Southern Agric., 43(3): pp. 294 - 301.

Abdul Khaliq, Muhammad, Sh. A., Naeem A. and Sohail R. (2018) 'Study on ratoon keeping of sugarcane crop at various harvesting dates' European Journal of Research, 7 (8): pp. 78 - 84.

Ahmed A. Z. (2003) 'Harvesting age with relation to yield and quality of some promising sugarcane varieties' Egypt J. Appl. Sci., 18 (7): pp. 114 - 124.

Ahmed A. Z., El-Bakry A. and Abazied R. S. (2016) 'Assessment of the optimum age for harvesting some promising sugar cane varieties' Minia J. of Agric. Res. \& Develop., 36(4): pp. 635 - 651.

Alida D. L., Orlando S.V., Rosaura B., Rea R. and Jose G. (2013) 'Promising sugarcane cultivars evaluation, selection and release in the Venezuelan regional trials network' Proc. Int. Soc. Sugar Cane Technol, Vol. 28.

Anand K., Amarendra K. and Parmhansh P. (2016) 'Phenotypic stability in sugarcane (Saccharum officinarum L.) through different classical parametric measures under saline-alkali condition' International Journal of Bio-resource and Stress Management, 7(4) Special: pp. 699 - 704.

Arumugam K., Arul J. S. and Prabhakar C. (2002) 'Studies on identification of suitable sugarcane varieties, months of planting and ages at harvest for maximizing cane yield and sugar recovery in late season' Proc. 64th Ann., Convention Sugar Technol. Assoc. India, Cochin, Kerala, India, 17-19 Aug., A156 - A172.

Bashir S., Hassan M., Naeem F., Khan Z.and Ali Z. (2013) 'Ratooning potential of different promising sugarcane genotypes at varying harvesting dates' ARPN Journal of Agricultural and Biological Science, 8(5): pp. 437 - 440. 
Bashir S., Naeem F., Abdul-Ghaffar and Farhan Kh. (2012) 'Ratooning ability of sugarcane genotypes at different harvesting dates' International Sugar Journal, 114 (1360).

Bissessur D., Lim Sh. Ch. L.C.Y., Ramnawaz C. and Ramdoyal K. (2001) 'Analyzing G x $\mathrm{E}$ interaction in sugarcane using the additive main effects and Multiplicative Interaction (AMMI) Model' Proc. Int. Soc. Sugar Cane Technol., 24: pp. 506 - 511.

Dubey R. B., Bharti B., Khandagale S. D. and Chittora K. (2017) 'Stability analysis for quantitative traits in sugarcane (Saccharumofficinarum L.)' Int. J. Curr. Microbiol. App. Sci., 6(4): pp. 1914 - 1918.

Dutra F. J. A., Junior T. C. and Simões N.D.E. (2014) 'Phenotype adaptability and stability of sugarcane genotypes in the sugarcane belt of the State of Pernambuco, Brazil' Genet. Mol. Res., 13(3): pp. 6865 - 6877.

Eberhart S. A. and Russell W. A. (1966) 'Stability parameters for comparing varieties' Crop Sci. 6: pp. 36 - 40.

Esayas T., Frehiwot G., Hussein M., Melaku T., Diribu T. and Abebech S. (2019) 'Genotype $\times$ environment interaction by AMMI and GGE-biplot analysis for sugar yield in three crop cycles of sugarcane (Saccharum officinirum L.) clones in Ethiopia' Cogent Food \& Agriculture, 5: 1651925.

Gilbert R. A., Shine J. M. Jr., Miller J. D., Rice R.W. and Rainbolt C. R. (2006) 'The effect of genotype, environment and time of harvest on sugarcane yields in Florida, USA' Field Crops Research, 95: pp. 156 - 170.

Gomez K. A. and Gomez A. A. (1984) 'Statistics for Agricultural Research (3rd ed.)' John Willey and Sons, New York. Pp. 142.

Guddadamath S. G., Patil S. B. and Khadi B. M. (2014) 'Stability analysis in elite genotypes of sugarcane (Saccharum spp., hybrid complex)'. Afr. J. Agri. Res., 9(37).
Hagos H., Walelign W. and Abuhay T. (2014a) 'Effect of drying off period and harvest age on quality and yield of ratoon cane (Saccharium officinarium L.)' Adv. Crop Sci. Tech. 2(3).

Hagos H., Mengistu L. and Mequanint Y. (2014b) 'Determining optimum harvest age of sugarcane varieties on the newly establishing sugar project in the tropical areas of tendaho, Ethiopia' Adv. Crop Sci. Tech., 2(5): pp. 156 - 159.

Hamam A. M., Kenawi M. N., Ferweez H. and Noha F. G. (2015) 'Effect of variety, harvest time and processing delay on sucrose content of sugarcane' Minia J. of Agric. Res. \& Develop. 35(1): pp. 1 - 24.

ImtiazA. Kh., Nighat S., Saboohi R., Shafquat Y. and Sajida B. (2013) 'Environmental interactions of sugarcane genotypes and yield stability analysis of sugarcane' Pak. J. Bot., 45(5): pp. 1617 - 1622.

Irlane T. B., Márcio H. P. B., Marcos D.V. R., Cássia Â. P., Cristiane G. M., Luiz A. P., Paulo M. A. C., Clariana V. X. and David C. F. B. (2009) 'Correlation among predicted genotypic values and adaptability and stability estimates of sugarcane clones in a mixed models context' Scientia Agraria,. 10(2).

Jun L., Yuan Z., Zhang H., Chen Y. and Chen R. (2009) 'Stability analysis on yield characters of sugarcane ratoon' China J. Appl Environ Bio., 15(4): pp. 488 - 494.

Jun L., Yong B. P., Liping X., Hua Z., Zhaonian Y., Zuhu D., Rukai Ch. and Youxiong Q. (2014) 'Cultivar Evaluation and Essential Test Locations Identification for Sugarcane Breeding in China' The Scientific World Journal, (302753): 10 pages.

Klomsa-ard P., Jaisil P. and Patanothai A. (2013) 'Performance and stability for yield and component traits of elite sugarcane 
genotypes across production environments in Thailand' Sugar Tech 15(4): pp. $354-364$. Mebrahtom F., Firew M. and Melaku T. (2017) 'Maturity classification of sugarcane (Saccharumofficinarum L.) genotypes grown under different production environments of Ethiopia' Adv. Crop Sci. Tech. 5: 5.

Mehareb E. M. and Sakina R. A. (2017) 'Genetic variability of some promising sugarcane varieties (Saccharum spp.) under harvesting ages for Juice quality traits, cane and sugar yield'Journal of Agricultural Research, 2(2).

Muhammad Kh., Hidayat R., Farhatullah, Ashiq R., David A. L., Muhammad I. and Imran Kh. (2018) 'The effect of two different agro-climatic conditions on growth and yield performance of sugarcane genotypes' Plant Gene and Trait, 9(1): pp. 1 - 13.

Osman M. S. H., Allabbody A. H. S. A. and Osman A. M. H. (2011) 'Performance of two promising sugarcane varieties under different harvesting dates' J. Plant Production, Mansoura Univ., 2(2): pp. 289 296.

Otieno V.O. (2016) 'Modeling genotype and environment interaction for performance stability and adaptability of sugarcane cultivars' M.Sc. Thesis, College of Biological and Physical Sciences, University of Nairobi.

Prema N. N., Khan M. G. M. and Jokhan A. D. (2017) 'Assessment of sugarcane varieties for their stability and yield potential in Fiji' The South Pacific Journal of Natural and Applied Sciences, 35(2): pp. 20 - 32.

Priyanka S., Manmohan S. and Sharma B.L. (2016) 'Variation in sugar content between early and mid-late maturing sugarcane varieties across the crushing period in subtropical India' Proceedings of the International Society of Sugar Cane Technologists, volume 29: pp. 1919-1922.
Queme J.L., Hector O. and Werner O. (2005) 'Analysis of genotype-by-environment interaction for sugarcane based on The AMMI model' Proc. ISSCT, Vol. 25.

Rajesh K. and Sinha O. K. (2015) 'Simultaneous selection of high yielding and stable mid-late maturing sugarcane genotypes of East Coast Zone in India using AMMI model: A new approach' Indian Journal of Sugarcane Technology, 30(1): pp. $19-27$.

Rakkiyappan P., Esther Sh. D., Gopalasundaram P., Mathew M. D. and Asokan S. (2009) 'Post-harvest deterioration of sugarcane with special reference to quality loss' Sugar Tech, 11 (2): pp. 167 - 170.

Ramburan S., Sewpersad C. and Mcelligott D. (2009) 'Effects of variety, harvest Age and eldana on coastal sugarcane production in South Africa' Proc. S. Afr. Sug. Technol. Ass., 82: pp. 580 - 588.

Rea R., Orlando S.V., Miguel R., Gleenys A., Alida D. and Rosaura B. (2011) 'Ammi analysis and its application to sugarcane regional trials in Venezuela' Sugar Tech, 13(2): pp. 108 - 113.

Rea R., Orlando S.V., Alida D., Miguel R., Briceño R., George J. and Niño M. (2014) 'Genotype-environment interaction in sugarcane by AMMI and Site regression models in Venezuela' Rev. Fac. Agron, (LUZ), 31: pp. 362 - 376.

Rea R., Orlando S.V., Alida D., Miguel R., Rosaura B., George J. and Jhonny D. (2015) 'Assessment of yield stability in sugarcane genotypes using non-parametric methods' Agronomía Colombiana 33(2): pp. 131 - 138.

Sphamandla S., Marvellous Z. and Maryke L. (2017) 'Location and crop-year effects on sugarcane genotype performance for the coastal short cycle breeding programs in South Africa' South African Journal of Plant and Soil, pp. 1 - 9.

Sugar crops Council (2019) 'Annual Report'. 
Sujeet P. S., Singh R. K., Nigam A. and Sharma B. L. (2017) 'Genotype environment interaction for sugar-related traits in sugarcane mapping population' Int. J. Curr. Microbiol. App. Sci., 6(7): pp. 4148 - 4159.

Tahir M., Hidayat R., Amjad A., Sajjad A. and Mohammad Kh. (2013) 'Assessment of genotype $\mathrm{x}$ environment interaction and stability of promising sugarcane genotypes for different agronomic characters in Peshawar Valley' American Journal of Experimental Agriculture, 3(1): pp. 142 151.

Tiawari D. K., Pandey P., Singh R. K., Singh S. P. and Singh S. B. (2011) 'Genotype $\times$ environment interaction and stability analysis in elite clones of sugarcane (Saccharum officinarum L.)' International Journal of Plant Breeding and Genetics 5(1): pp. 93 - 98.

Viator R. P., Dalley C. D., Johnson R. M. and Richard E. P. Jr. (2010) 'Early harvest affects sugarcane-ratooning ability in Louisiana' Sugar cane International, 28(3).

Yohannes M. and Netsanet A. (2014) 'Effect of harvesting age on yield of exotic sugarcane varieties at Metahara Sugar Estate' The Journal of Agriculture and Natural Resources Sciences, 1(4): pp. 227 - 231. 